\title{
Perancangan Alat Pencegah Kebakaran Rumah Akibat Kelalaian Manusia Mematikan Kompor Gas Berbasis Mikrokontroler Arduino yang Terintegrasi dengan Smartphone
}

\author{
Surawan Setiyadi dan Dendra Alfi Nugroho \\ Program Studi Teknik Elektro, Universitas Presiden, Bekasi 17550, Indonesia \\ Penulis koresponden: surawan @ president.ac.id
}

\begin{abstract}
ABSTRAK
Banyak yang tahu bahwa aktivitas kebanyakan orang yang berada di rumah pasti tidak dapat di jauhkan dari yang namanya masak memasak dengan kompor gas. Namun hal itu menjadi perhatian karena banyaknya kasus yang terjadi berkaitan dengan kompor gas. Sering dari kebanyakan orang ketika memasak mereka melupakan untuk mematikan kompor di karenakan kesibukan yang lain atau bahkan sampai di tinggal pergi. Hal tersebut dapat menimbulkan potensi kebakaran rumah. Untuk mengatasi masalah itu maka diperlukan suatu alat yang bisa mendeteksi kondisi kompor gas tersebut, agar mencegah terjadinya hal-hal yang tidak diinginkan lebih dini. Untuk menghindari kejadian yang tidak diinginkan karena adanya kelalaian manusia mematikan kompor gas. Maka perancangan pembuatan alat yang dapat mengetahui ada tidaknya aktifitas benda bergerak di depan kompor gas. Sehingga jika kompor gas masih menyala maka kompor gas tersebut akan mati dengan sendirinya atau dimatikan secara remote oleh pemilik rumah dengan cara memberikan notifikasi ke handphone pemilik rumah.
\end{abstract}

Kata kunci: benda bergerak, kompor gas, notifikasi

\begin{abstract}
Many know that the activities of most people who are at home certainly cannot be kept away from the name of cooking with gas stoves. But it was a concern because of the many cases that occurred related to gas stoves. Often from most people when cooking they forget to turn off the stove because of other activities or even leave. This can lead to potential house fires. To overcome this problem, we need a tool that can detect the condition of the gas stove, in order to prevent undesirable things from happening earlier. To avoid undesirable events due to human negligence turning off the gas stove. So the design of making tools that can determine whether there is activity of moving objects in front of the gas stove. So that if the gas stove is still burning, the gas stove will automatically turn off or be turned off remotely by the homeowner by giving notification to the homeowner's handphone.
\end{abstract}

Keywords: gas stoves, moving object, notification

\section{Pendahuluan}

Kebakaran adalah peristiwa yang tidak diharapkan dan terkadang tidak bisa dikendalikan. Maka dari itu sifatnya yang mengganggu dan membahayakan kehidupan dalam masyarakat, oleh sebab itu kebakaran merupakan salah satu jenis dari bentuk bencana. Menurut BNPB (Badan Nasional Penanggulangan Bencana), bencana merupakan "sebuah kejadian atau rangkaian kejadian yang disebabkan faktor alam karena mengganggu kehidupan dalam masyarakat, bisa juga karena faktor bukan dari alam, ataupun faktor dari manusia sehingga menyebabkan jatuhnya korban jiwa, kerugian harta, kerusakan lingkungan maupun harta benda dan tentunya psikologis" [1]. Daerah perkotaan merupakan salah satu wilayah yang sering kali terjadi bencana kebakaran. Dari data yang di peroleh melalui BPBD-PK (Badan Penanggulangan Bencana Daerah Pemadam Kebakaran) kota Padang, kejadian kebakaran selama tahun 2015 sebanyak 357 yang telah terjadi di kota Padang ,dan kerugiannya ditaksir lebih dari 34.5 miliar Rupiah [2].

Dan bencana kebakaran yang terjadi di provinsi DKI Jakarta bahkan mencapai sekitar 800 kasus per-tahun atau dalam sebulan mencapai 67 kasus [3]. Dari data tersebut dapat dikategorikan bahwa peristiwa kebakaran yang terjadi di kota besar perlu mendapatkan perhatian yang serius, terutama dalam hal penanggulangan maupun pencegahannya. Pada umumnya kasus kebakaran di kota besar berdasarkan data terjadi karena hubungan singkat arus listrik (korsleting), pipa gas LPG mengalami kebocoran, atau disebabkan karena kelalaian manusia 
lupa mematikan kompor yang menyala atau setelah digunakan, api dari sampah yang di bakar atau sisa puntung rokok yang masih menyala. Selain itu kebakaran bukan saja karena faktor dari manusia saja tetapi juga di sebabkan oleh faktor alam seperti petir, letusan gunung api, gempa bumi, kemarau panjang dan lain sebagaianya. Salah satu cara untuk mencegah kebakaran yang diakibatkan oleh kebocoran gas di rumah tangga adalah menggunakan alat pendeteksi kebocoran gas yang banyak kita jumpai dipasaran. Namun harga dari alat tersebut cukup mahal dan pemakaian yang terlalu rumit untuk dipasang pada rumah penduduk pada umumnya. Selain itu untuk sistem penegndalinya hanya terbatas di area tersebut saja. Sehingga kebocoran dapat di ketahui hanya orang yang sedang berada ditempat itu saja. Hal ini berbanding terbalik dengan kehidupan masyarakat urban pada saat ini, mereka cenderung suka berada di luar rumah.

\section{DASAR TEORI}

\section{A. Sensor PIR (Passive Infra Red)}

Sensor PIR adalah sensor yang biasa digunakan untuk menangkap pancaran dari sinar inframerah dari objek tertentu. Sensor ini memiliki sifat pasif sesuai dengan namanya, dalam arti sensor tersebut hanya bisa menerima pancaran sinar inframerah dari luar dan bukan memancarkan radiasi sinar inframerah. Sensor PIR mendeteksi berbagai macam objek, tentunya objek yang memancarkan energi radiasi. Gambar sensor PIR seperti terlihat pada Gambar 1 di bawah ini.

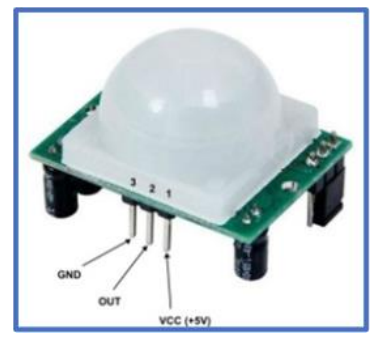

Gambar 1. Sensor PIR [4]

Spesifikasi sensor PIR:

1. Sebagai pengatur lama pulsa high yang terdeteksi adanya gerakan sampai tidak ada gerakan (Pengatur Waktu Jeda).

2. Sebagai pengatur sensitivitas sensor (Pengatur Sensitivitas Sensor)

3. Sebagai penstabil tegangan 3 VDC (Regulator 3 VDC)

4. Untuk pengaman sensor apabila terdapat salah pengkabelan dari VCC dan GND (Dioda)

5. Sebagai sumber tegangan dengan rentang 3-12 VDC (DC Power)
6. Sebagai keluaran digital sensor (Output Digital Sensor)

7. Sebagai Grounding (GND) IC Sensor PIR (BISS0001)

8. Sebagai pengatur output dari pin digital (Pengatur Jumper)

Untuk melakukan kalibrasi sensor PIR menggunakan pin nomor 1 dan 2 caranya mengatur posisi potentiometer pada posisi label MIN ata MAX [5].

\section{B. Arduino NodeMCU}

Sebuah open source platform internet of think (IoT) dan pengembangan kit dengan menerapkan bahasa pemrograman Lua dikenal dengan nama NodeMCU. NodeMCU yang terlihat pada Gambar 2 dapat juga di program menggunakan sketch yang dibuat dengan Arduino IDE. Modul ESP8266 yang menjadi dasar pengembangan kit ini, yang mengintegrasi GPIO, Pulse Width Modulation (PWM), IIC , 1-Wire dan Analog to Digital Converter (ADC) semua dalam satu papan. Papannya yang berukuran sangat kecil merupakan keunikan dari NodeMCU, ukuran panjangnya $4.83 \mathrm{~cm}$ dan lebarnya $2.54 \mathrm{~cm}$ dengan beratnya kurang lebih 7 gram. NodeMCU tersebut sudah dilengkapi dengan fitur wifi dan firmware-nya yang bersifat opensource meski ukurannya yang kecil.

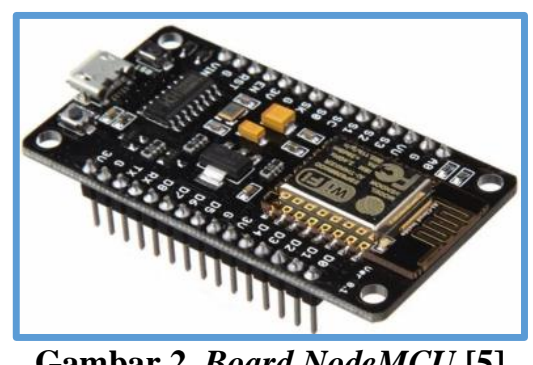

\section{OLED (Organic Light Emitting Diode)}

OLED tersusun dari kaca berlapis yang dibuat dari oksida timah indium yang memiliki fungsi sebagai elektroda positif. Lapisan organik terbuat dari diamine aromatic dengan tebal $750 \mathrm{~nm}$, lapisan pemancar cahaya yang dibuat dari senyawa metal kompleks seperti 8 hydroxyquinoline alumunium, dan lapisan elektroda negatif atau katoda terbuat dari pencampuran logam magnesium dan perak dengan skala atom 10:1. Ketebalan dari lapisan tidak lebih dari $500 \mathrm{~nm}$, struktur ini tebalnya mirip dengan selembar kertas. Lapisan elektroda dan lapisan tipis yang tersusun bertumpuk dari molekul molekul organik sebagai pemancar cahaya, ini merupakan bagian piranti OLED yang penting. Bentuk fisik dari OLED dapat dilihat pada Gambar 3 di bawah ini. 


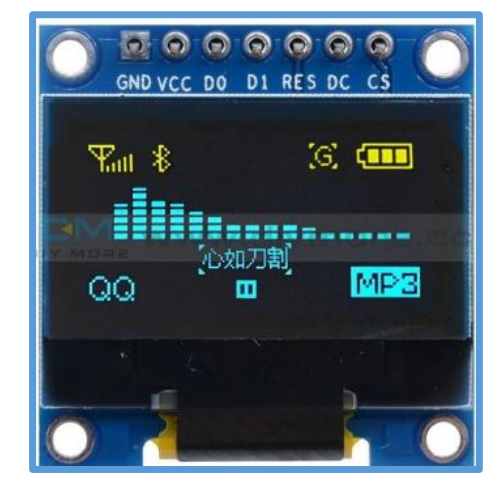

Gambar 3. Bentuk fisik OLED [6]

\section{IMPLEMENTASI DESAIN}

\section{A. Perancangan Sistem}

Secara keseluruhan alat ini tersusun atas bagianbagian penting yang saling berhubungan satu sama lain yaitu perangkat keras (hardware) dan bagian program. Bagian hardware terdiri dari HC-6, rangkaian sensor gas, rangkaian relai, rangkaian buzzer dan Arduino. Bagian program terdiri dari program berbasis bahasa $\mathrm{C}$ yang disuntikan ke dalam mikrokontroler Arduino UNO R3, untuk mengatur dan mengaktifkan sensor yang digunakan sebagai pengendali sensor gas, mengaktifkan fan sebagai pengurai gas ketika terjadi konsentrasi gas serta buzzer sebagai penanda ketika terjadi kebocoran gas di area tersebut. Blok diagram perancangan sistem pencegah kebakaran pada rumah terlihat pada Gambar 4 di bawah ini.

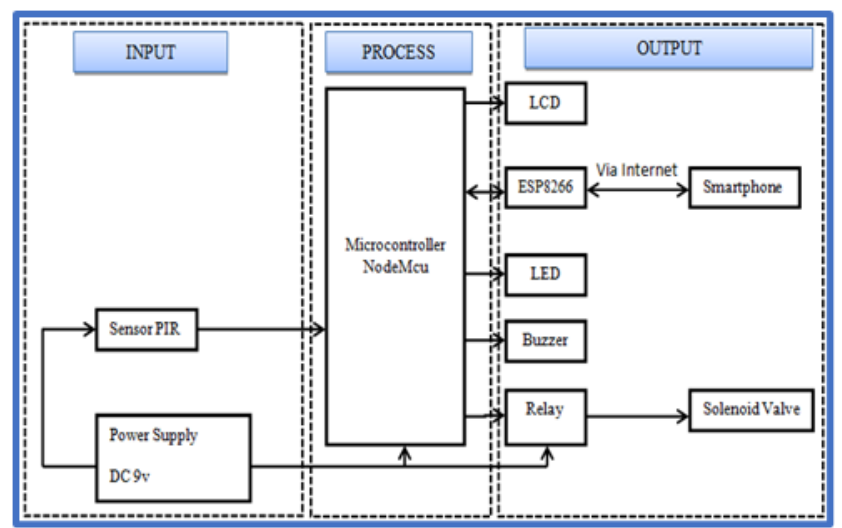

Gambar 4. Blok diagram perancangan

\section{B. Prinsip Kerja}

Prinsip kerja dari pendeteksi dan pencegah kebakaran rumah yang berbasis mikrokontroler tersebut dapat dilihat pada blok diagram pada Gambar 4 diatas. Pada saat sensor PIR ini mendeteksi tidak ada benda yang bergerak pada ruangan maka buzzer akan menyala sebagai alarm. Jika tidak ada benda yang bergerak di sekitar kompor maka solenoid valve akan menutup aliran gas ke kompor untuk menghentikan aliran gas-nya dan mencegah kebakaran. Modul wifi ESP8266 akan mendapatkan perintah oleh Arduino yang telah diprogram untuk mengirim notifikasi melalui daring di handphone pemilik rumah. Penentuan waktu adanya gerakan sendiri di bagi menjadi 2 tingkatan, yaitu: batas aman di tunjukan dengan lampu warna hijau menyala $(<20$ menit), batas siaga di tunjukan dengan lampu warna merah menyala (20 menit $<\mathrm{x}<22$ menit). Layout rangkaian dari hasil perancangan dapat dilihat pada Gambar 5 sedangkan desain panel elektronik untuk meletakkan komponen terlihat pada Gambar 6 di bawah ini.

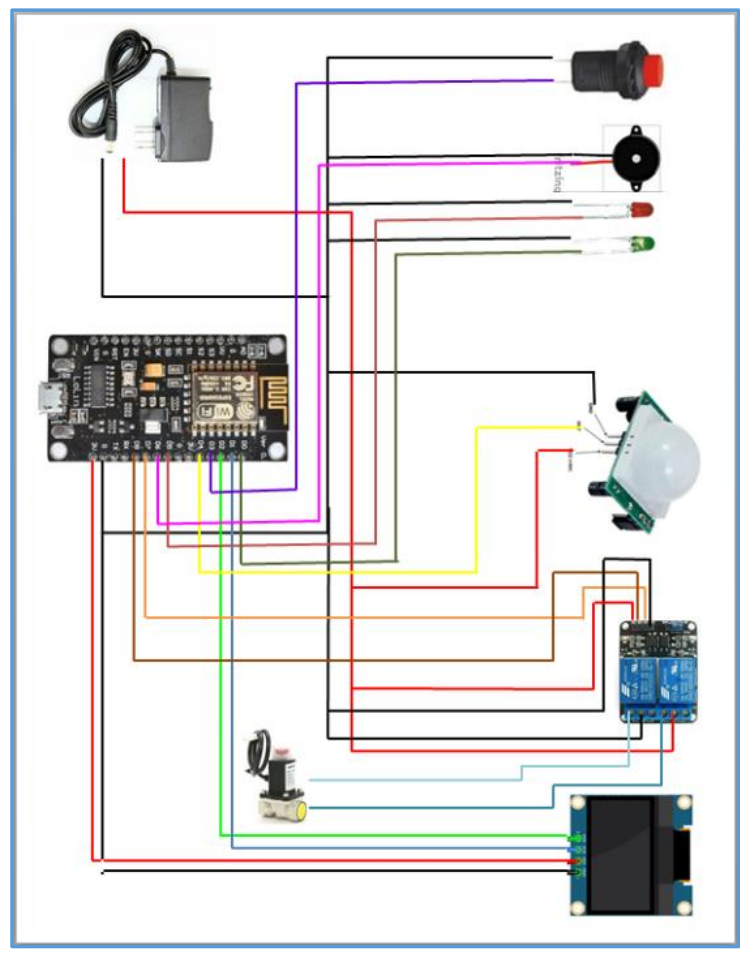

Gambar 5. Layout rangkaian

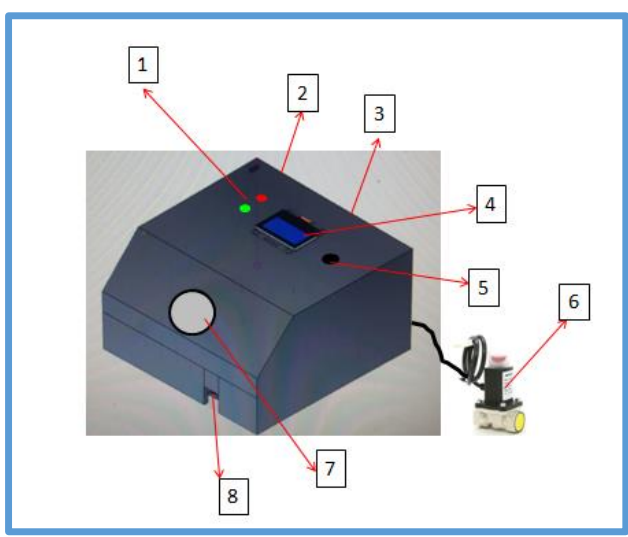

Gambar 6. Desain panel elektronik 
Bagian-bagian desain panel untuk meletakkan komponen elektronik pada Gambar 6 dapat dijelaskan seperti berikut:

1. LED sebagai indicator penunjuk kondisi saat ini

2. Power supply sebagai sumber tenaga untuk menyalakan sistem.

3. Buzzer berfungsi sebagai tanda peringatan suara ketika tidak ada orang di sekitar.

4. OLED untuk menampilkan indikasi alarm kebakaran dan nilai gas yang di deteksi.

5. Switch untuk power control.

6. Solenoid valve berfungsi untuk membuka dan menutup aliran gas.

7. Sensor PIR sebagai pendeteksi gerakan.

8. USB Port untuk mensuntikkan program ke dalam NodeMCU dan sebagai supply.

\section{Perancangan dan Pembuatan Program}

Setelah perancangan dan pembuatan hardware selesai, langkah selanjutnya yang di lakukan adalah pembuatan dan perancangan program. Pada perancangan program ini meliputi pemograman dengan menggunakan bahasa C. Agar perancangan program mudah dilakukan maka terlebih dahulu membuat sebuah diagram flowchart atau diagram alir untuk menggambarkan jalannya program secara keseluruhan. Diagram alir program terlihat pada Gambar 7 di bawah ini.

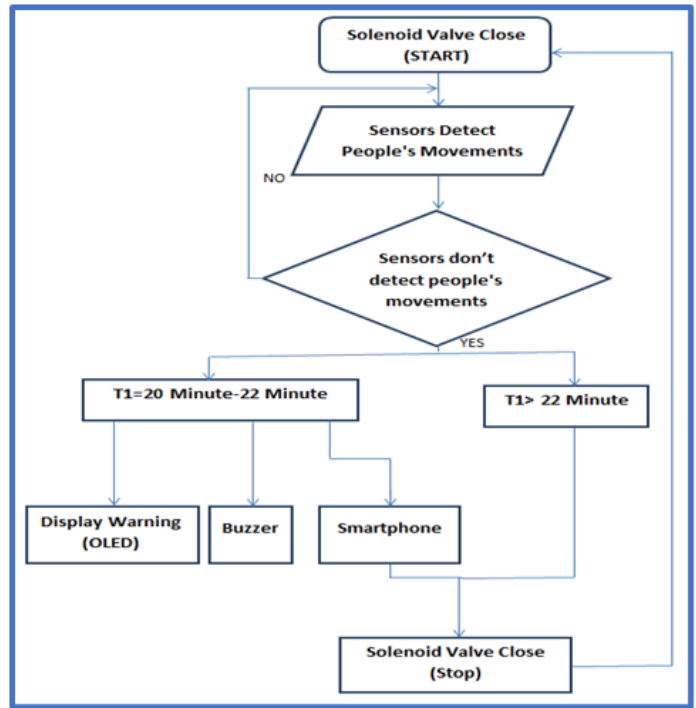

Gambar 7. Diagram alir pemrograman

\section{HASIL dan PEMbahasan}

\section{A. Pengujian Sensor PIR}

Pengujian terhadap sensor PIR bertujuan untuk mengetahui kemampuan sensor dalam mendeteksi adanya aktivitas manusia di ruangan. Dengan cara bergerak di depan sensor PIR dan jika sensor mendeteksi adanya aktivitas benda bergerak, maka sensor akan terus membaca. Jika tidak ada aktivitas pergerakan benda, maka sensor akan memastikannya selama 1 menit. Kemudian timer akan bekerja selama 22 menit. Jika sensor tetap tidak mendeteksi pergerakan benda, maka sistem akan mengirimkan tanda peringatan dan akan menutup valve. Saat sensor mendeteksi keberadaan benda, maka valve dalam kondisi membuka (valve open), LED warna hijau menyala dan LED merah tidak menyala, dan di aplikasi handphone terlihat ada notifikasi "valve open" yang terlihat pada Gambar 8. Setelah timer mencapai 22 menit tanpa adaya aktivitas pergerakan benda di depan sensor, maka valve akan menurup, di tandai dengan LED warna merah menyala dan notifikasi di handphone yang sudah terinstal aplikasi Blynk [7] yaitu "valve close" seperti terlihat pada Gambar 9 di bawah ini.

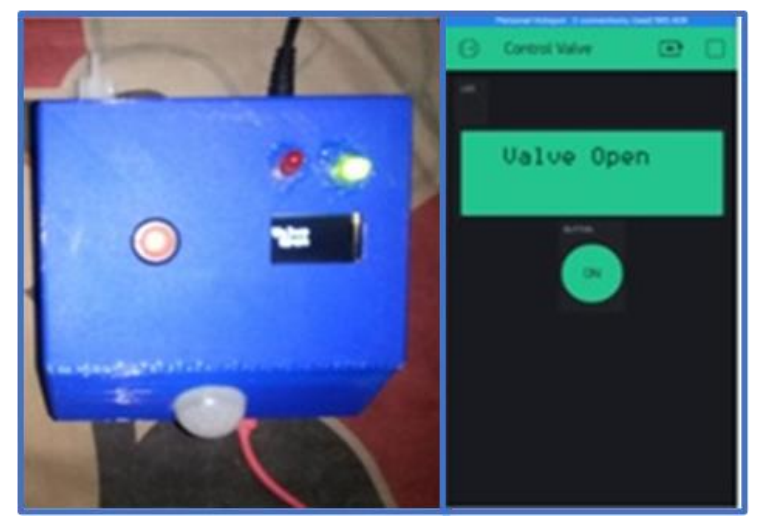

Gambar 8. Valve open saat ada pergerakan di depan sensor

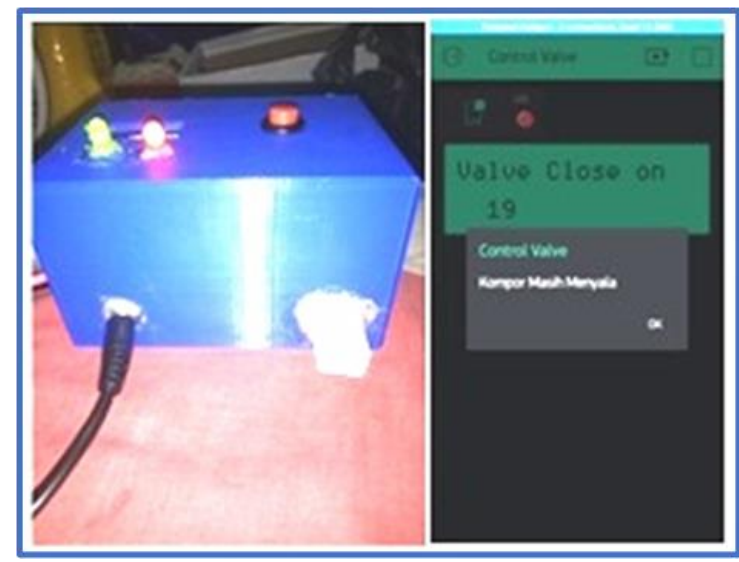

Gambar 9. Valve close saat tidak ada pergerakan di depan sensor

\section{Pengujian PIR terhadap objek}

Tujuan dari pengujian sensor berikut untuk mengetahui sensitivitas sensor dalam menangkap objek baik pada jarak dekat atau jauh terhadap objek yang di depan pintu, dimana sensor ini membutuhkan tegangan masukan sebesar $9 \mathrm{~V}$ DC. Sensor ini akan 
diletakkan pada bagian dalam ruangan yang menghadap ke pintu untuk mendeteksi objek yang berada di dalam bangunan. Objek yang akan di deteksi di dalam pengujian yaitu manusia dan pintu, Percobaan ini dilakukan sebanyak 7 (tujuh) kali dari setiap objek pada jarak 1 sampai 7 meter. Berikut ini hasil pengujian sensitivitas sensor PIR terhadap objek dan dapat kita lihat pada Tabel 1 di bawah ini:

Tabel 1. Pengujian Sensitivitas PIR Terhadap Objek

\begin{tabular}{|c|c|c|c|}
\hline Objek & Jarak(Meter) & Respon & $\begin{array}{c}\text { Tegangan } \\
\text { Output(vdc) }\end{array}$ \\
\hline \multirow{4}{*}{ Manusia } & 1 & aktif & 8,96 \\
\cline { 2 - 4 } & 3 & aktif & 8,98 \\
\cline { 2 - 4 } & 4 & aktif & 8,96 \\
\cline { 2 - 4 } & 5 & aktif & 8,96 \\
\cline { 2 - 4 } & 6 & Tidak aktif & 0,00 \\
\cline { 2 - 4 } & 7 & Tidak aktif & 0,00 \\
\hline \multirow{4}{*}{ Pintu } & 1 & Tidak aktif & 0,00 \\
\cline { 2 - 4 } & 3 & Tidak aktif & 0,00 \\
\cline { 2 - 4 } & 4 & Tidak Aktif & 0,00 \\
\cline { 2 - 4 } & 5 & Tidak aktif & 0,00 \\
\cline { 2 - 4 } & 6 & Tidak Aktif & 0,00 \\
\cline { 2 - 4 } & 7 & Tidak Aktif & 0,00 \\
\hline
\end{tabular}

Dari data hasil pengujian diperoleh bahwa sensor PIR bekerja saat objek manusia pada jarak 1 sampai 5 meter, sedangkan ketika objek berupa pintu yang terlihat pada Gambar 10 sensor PIR tidak bekerja atau tidak merespon.

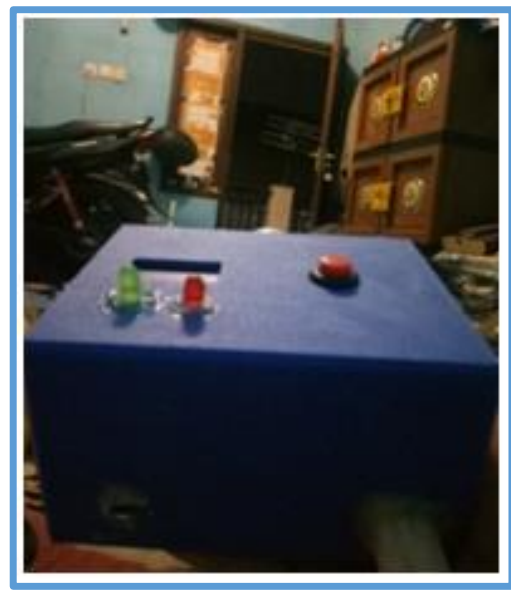

Gambar 10. Pengujian sensor PIR objek pintu

\section{Pengujian sensor terhadap sudut pembacaan}

Tujuan dari pengujian sensor berikut untuk mengetahui sensitivitas sensor berdasarkan sudut pembacaan dari sensor. Sudut pembacaan yang akan diuji adalah sudut $0^{\circ}, 30^{\circ}, 60^{\circ}$ dan $90^{\circ}$. Sensor akan membace objek manusia dan percobaan ini dilakukan sebanyak 7 (tujuh) kali dari setiap objek pada jarak 1 sampai 7 meter. Berikut ini hasil pengujian sensitivitas sensor PIR terhadap objek yang terdata pada Tabel 2.
Tabel 2. Pengujian Sensitivitas PIR Sudut Pembacaan

\begin{tabular}{|c|c|c|c|}
\hline Sudut & Jarak(Meter) & Respon & $\begin{array}{r}\text { Tegangan } \\
\text { Output(vdc) }\end{array}$ \\
\hline \multirow{6}{*}{$0^{\circ}$} & 1 & aktif & 8,96 \\
\hline & 3 & aktif & 8,96 \\
\hline & 4 & aktif & 8,96 \\
\hline & 5 & aktif & 8,96 \\
\hline & 6 & Tidak aktif & 0,00 \\
\hline & 7 & Tidak aktif & 0,00 \\
\hline \multirow{6}{*}{$30^{\circ}$} & 1 & aktif & 8,96 \\
\hline & 3 & aktif & 8,96 \\
\hline & 4 & aktif & 8,96 \\
\hline & 5 & aktif & 8,96 \\
\hline & 6 & Tidak Aktif & 0,00 \\
\hline & 7 & Tidak Aktif & 0,00 \\
\hline Sudut & Jarak(Meter) & Respon & $\begin{array}{r}\text { Tegangan } \\
\text { Output(vdc) }\end{array}$ \\
\hline \multirow{6}{*}{$60^{\circ}$} & 1 & aktif & 8,96 \\
\hline & 3 & aktif & 8,96 \\
\hline & 4 & aktif & 8,96 \\
\hline & 5 & aktif & 8,96 \\
\hline & 6 & Tidak aktif & 0,00 \\
\hline & 7 & Tidak aktif & 0,00 \\
\hline \multirow{6}{*}{$90^{\circ}$} & 1 & Tidak Aktif & 0,00 \\
\hline & 3 & Tidak Aktif & 0,00 \\
\hline & 4 & Tidak Aktif & 0,00 \\
\hline & 5 & Tidak Aktif & 0,00 \\
\hline & 6 & Tidak Aktif & 0,00 \\
\hline & 7 & Tidak Aktif & 0,00 \\
\hline
\end{tabular}

\section{B. Pengujian OLED}

Pengujian ini bertujuan untuk memastikan bahwa OLED dapat beroperasi dan berfungsi dengan baik, sehingga pada saar proses monitoring, didapatkan data yang baik dan sesuai.

\section{Kondisi normal}

Kondisi normal adalah kondisi dimana sensor mendeteksi keberadaan objek yang bergerak di sekitar ruangan. Hasil dari pengujian saat kondisi normal seperti terlihat pada Tabel 3 dan Gambar 11 adalah pada kondisi normal.

\section{Tabel 3. Kondisi Normal}

\begin{tabular}{|c|c|}
\hline Keluaran & Kondisi \\
\hline Solenoid Valve & Open \\
\hline Buzzer & Off \\
\hline Lampu Indikator & Hijau \\
\hline
\end{tabular}

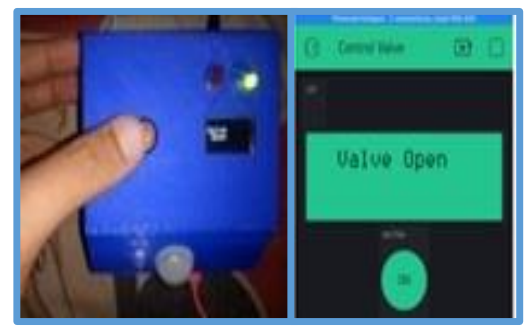

Gambar 11. Pengujian OLED kondisi normal

2. Kondisi tidak normal

Kondisi tidak normal adalah kondisi di mana sensor tidak mendeteksi aktivitas objek bergerak di ruangan. Hasil dari pengujian saat kondisi tidak 
normal seperti terlihat pada Table 4 dan Gamabr 12 adalah pada kondisi tidak normal.

Tabel 4. Kondisi tidak normal

\begin{tabular}{|c|c|}
\hline Keluaran & Kondisi \\
\hline Solenoid Valve & Close \\
\hline Buzzer & On \\
\hline Lampu Indikator & Merah \\
\hline
\end{tabular}

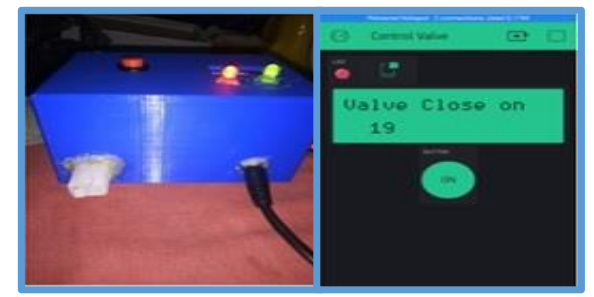

Gambar 12. Pengujian OLED kondisi tidak normal

\section{Kelebihan dan Kekurangan}

\section{Kelebihan}

a) Mudah dioperasikan oleh siapa saja, kapan saja dan dimana saja. Sebab alat yang dibuat sederhana dan kompak sehingga dapat di sesuaikan penggunaannya pada area yang kita inginkan.

b) Respon pencegahan kebakaran kompor gas lebih cepat. Dengan ditambahkannya port external untuk buzzer dan lampu pada alat yang dibuat, ketika tidak ada keberadaan orang di ruangan sedangkan kompor gas masih menyala. Maka dari itu kebakaran dapat dicegah lebih awal walaupun kita tidak sedang berada di area tersebut. Hal ini sangatlah penting mengingat ketika kita terlambat melakukan antisipasi, maka potensi terjadinya kebakaran yang merugikan kita selaku pemilik rumah tersebut.

c) Jangkauan area monitoring lebih luas karena mnggunakan tekhnologin IoT. Dengan menggunakan internet maka kita bisa mendapatkan informasi dimanapun kita berada asalkan terdapat akses internet di tempat itu.

2. Kekurangan

a) Akses alat memerlukan internet. Karena menggunkan mikrokontroler NodeMCU, maka alat ini untuk menjalankannya harus terhubung ke internet melalui wifi. Jadi jika tidak terdapat wifi di ruangan maka sistem tidak akan berjalan.

b) Terbatas pada ruang lingkup tertentu. Karena sensor memiliki tingkat sensitifitas pada ruang terbatas, karena pembacaan sensor hanya membentuk sudut 90 derajat dari permukaan sensor. Jadi jika objek membelakangi sensor, maka sensor tidak akan bisa mendeteksi.

\section{KESIMPUlan DAN SARAN}

\section{A. Kesimpulan}

1. Kemampuan mikrokontroller untuk mengendalikan rangkaian berjalan lancar dan mendeteksi tidak adanya aktivitas pergerakan objek di sekitar ruangan, mengirimkan notifikasi dan dapat dicegah dari jarak jauh.

2. Pendeteksi keberadaan manusia hanya sampai dengan 5 meter dan sudut hingga $60^{\circ}$, yang artinya bahwa untuk jarak dan sudut yang lebih dari tabel percobaan, sensor akan memberikan sinyal ke NodeMCU dan OLED dan buzzer akan memberikan notifikasi bahwa kompor belum dimatikan sedangkan kondisi di dalam ruangan tidak ada objek yang bergerak.

\section{B. Saran}

1. Alat ini masih mampu untuk dikembangkan lagi, tidak hanya bersifat pencegahan menggunakan detektor gerak, akan tetapi bisa ditambahkan dengan sensor deteksi kebocoran gas

2. Pengembangan yang lain yaitu dapat digabungkan dengan Alat Pemadam Api Ringan (APAR) berupa semprotan bubuk jika telah terjadi kebakaran di area tersebut.

\section{Daftar Pustaka}

[1] Badan Nasional Penanggulangan Bencana, Definisi bencana 2016. [Online]. Available: https://bnpb.go.id/home/definisi. [Accessed September 1, 2016]

[2] Harian Haluan, Kasus kebakaran kota Padang, 2016. [Online] Available:

https://www.harianhaluan.com/news/detail/47666/357kebakaran-terjadi-di-padang. [Accessed September 1, 2016].

[3] Badan Nasional Penanggulangan Bencana, Kasus kebakaran kota Jakarta, 2016. [Online]. Available: https://bnpb.go.id/. [Accessed September 1, 2016].

[4] Abu Dawud, Sensor Passive InfraRed, 2016. [Online] Available:

https://abudawud.wordpress.com/2018/06/02/mengenalsensor-pir-passive-infrared/. [Accessed September 2, 2016]

[5] Future Electronics, NodeMCU ESP8266, 2016. [Online]. Available: https://store.fut-electronics.com/products/nodemcuesp8266-programming-and-development-kit. [Accessed September 2, 2016]

[6] DIY More, OLED LCD display for Arduino, 2016. [Online] Available: https://www.diymore.cc/products/0-96-i2c-iic-spiserial-128x64-oled-lcd-display-ssd1306-for-arduino-51stm32-white-blue-blue-yellow-optional. [Accessed September 2, 2016]

[7] Blynk.Inc, Blynk application, 2016. [Online]. Available: http://www.Blynk.cc. [Accessed September 3, 2016] 